2016 - Volume: 17 Number: 3

Page: 572 - 584

DOI : $10.18038 / \mathrm{btda} .67184$

Received: 17 June 2016 Revised: 13 July 2016 Accepted: 04 August 2016

\title{
URBAN WATER LOSSES MANAGEMENT IN TURKEY: THE LEGISLATION AND CHALLENGES
}

\section{Ethem KARADİREK*}

\author{
Department of Environmental Engineering, Akdeniz University, Antalya, Turkey
}

\begin{abstract}
Water losses from water distribution networks (WDNs) have become a crucial problem in many countries such as Turkey, where country average non-revenue water (NRW) is almost $45 \%$ of system input volume (SIV). Municipalities are responsible for water supply in Turkey but only a few of them have started to improve their WDNs for management of water losses and provide good application examples; whereas many of the other municipalities have no activities to reduce water losses. The Turkish Ministry of Forestry and Water Affairs issued a new directive to control and reduce water losses from WDNs recently. With the issue of the new directive, all municipalities are now obliged to reduce water losses in WDNs within a given time frame. This paper represents a discussion and evaluation for the contents of the new Turkish directive on water losses management for the first time. Moreover, other existing guidelines and some country practices are presented to provide recommendations for the management of urban water losses. Reduction of water losses contributes directly to protection of water quality in WDNs and public health.
\end{abstract}

Keywords: Apparent water losses, Management challenges of water losses, Physical water losses, Urban water losses management, Water losses directive in Turkey

\section{INTRODUCTION}

Water resources are currently under pressure due to climate change and increasing water demand, caused by the increase in population, urbanization and industrialization [1,2]. Thus, sustainable water management is becoming more crucial. A World Bank study showed that each year more than 32 billion $\mathrm{m}^{3}$ of treated water is lost due to leakage from WDNs around the world, while 16 billion $\mathrm{m}^{3}$ of water is used but not paid [3].

The difference between system input volume (SIV) and authorized consumption is defined as water losses while the difference between SIV and billed water consumption is defined as non-revenue water (NRW) [4]. Water losses in water distribution networks (WDNs) are classified as real/physical losses and commercial/apparent losses. Real losses are mainly due to leakage on transmission and distribution mains, leakage on service connections and leakage and overflows at storage tanks while apparent losses are mainly due to unauthorized consumption, customer meter inaccuracies and data handling errors [5, 6]. Water losses from WDNs are not only a revenue problem but it also results in waste of sources such as water, energy and chemicals [7]. Management of water losses from WDNs results in: i. reducing demand on water supplies, ii. reducing costs and energy demand for water abstraction, transmission and treatment chemicals needed for treatment and supply. Reducing water losses from WDNs provides additional water for future demands and water authorities save time and money by postponing their projects on water supply and infrastructure. However, most of the water authorities are not fully aware of these facts [8]. Financial gains from reduced water production increase water revenue. Also, possible delay of capacity expansion of water supply system could be achieved by reducing water losses from WDNs. Moreover, leakage points may provide intrusion pathways under negative pressure conditions in WDNs [9]. Consequently, water losses problem from WDNs is not only economic and environmental but also a public health issue [10]. Reduction of physical water losses reduces the risk of potential

*Corresponding Author: ethemkaradirek@akdeniz.edu.tr 
contamination from leak points. Accordingly, many utilities have started to develop methods to control water losses from WDNs $[11,12,13]$.

International Water Association (IWA) developed the standard water balance concept to create a common terminology for evaluation of WDNs [14]. Later on, IWA standard water balance was modified by introducing economic dimensions of the volumetric IWA standard water balance [15] and also adding a minimum charge difference component [16]. IWA developed a set of 170 performance indicators (PIs) for assessment of water distribution efficiency [17]. The basic and most widely used PIs provided by IWA are i) total water losses and real losses as a percentage of SIV, ii) volume of real water losses per service connection per unit time, iii) volume of real water losses per property per unit time, iv) volume of real water losses per length of system per unit time, where length of system equals to sum of length of mains and length of service connections up to point of customer metering, v) infrastructure leakage index (ILI) which is the ratio of current annual real losses (CARL) to unavoidable annual real losses (UARL) [18]. ILI has no unit which makes it suitable for comparison between different WDNs in different countries and is an efficient tool for assessment of WDNs in terms of management of real water losses at current operating pressure [18]. ILI was developed by considering the fact that real water losses cannot be eliminated totally. A simple matrix was developed, which can be used for classification of real water losses in WDNs, as given in Table 1 [19].

Table 1. Real water losses assessment matrix [19]

\begin{tabular}{|c|c|c|c|}
\hline \multicolumn{2}{|c|}{ ILI } & \multirow[b]{2}{*}{ Band } & \multirow[b]{2}{*}{ General description of categories } \\
\hline $\begin{array}{c}\text { Developed } \\
\text { Countries }\end{array}$ & $\begin{array}{c}\text { Developing } \\
\text { Countries }\end{array}$ & & \\
\hline $1-2$ & $1-4$ & A & $\begin{array}{l}\text { Further loss reduction may be uneconomic unless } \\
\text { there are shortages; careful analysis is needed to } \\
\text { identify cost-effective improvement }\end{array}$ \\
\hline $2-4$ & $4-8$ & B & $\begin{array}{l}\text { Potential for marked improvements; consider } \\
\text { pressure management, better active leakage control } \\
\text { practices, and better network maintenance }\end{array}$ \\
\hline $4-8$ & $8-16$ & $\mathrm{C}$ & $\begin{array}{l}\text { Poor leakage record; tolerable only if water is } \\
\text { plentiful and cheap; even then, analyze level and } \\
\text { nature of leakage and intensify leakage reduction }\end{array}$ \\
\hline$>8$ & $>16$ & $\mathrm{D}$ & $\begin{array}{l}\text { Very inefficient use of resources; leakage reduction } \\
\text { programs are imperative with high priority }\end{array}$ \\
\hline
\end{tabular}

The lowest achievable annual volume of real losses for well-managed systems is named as UARL which can be calculated using the following equation developed by IWA Water Loss Task Force [4].

$$
U A R L=\left(18 x L_{m}+0,8 x N_{c}+25 x L_{p}\right) x P
$$

where $\mathrm{L}_{m}$ is the length of mains in $\mathrm{km}, \mathrm{N}_{\mathrm{c}}$ is the number of service connections, $\mathrm{L}_{\mathrm{p}}$ is the total length of underground pipe between the edge of the street and customer meters in $\mathrm{km}$, and $\mathrm{P}$ is the average operating pressure in meters [4].

\subsection{Methods for Water Losses Reduction}

The formation of district metered areas (DMAs) which makes it possible to divide WDNs into small, isolated WDNs provides an efficient way to manage water losses [7, 20,21]. There are four basic methods to control real water losses: i) pressure management, ii) active leakage management, iii) pipeline and assets management and iv) speed and quality of repairs [22]. Pressure management, which can be achieved by implementing DMAs, aims to reduce excess water pressure in WDNs, whereas active leakage management aims identifying and quantifying physical losses on a regular basis, basically by 
performing acoustic leakage methods. Pressure management through hydraulic modeling, is also reported as an efficient tool to reduce real losses from WDNs [23]. Pipeline and assets management, which aims to increase efficiency while reducing costs, deals with the management of all physical components of WDNs such as pipe, valves and pumps. Speed of repairs affects the volume of real losses in case of pipe bursts whereas repair quality is important for sustainability. On the other hand, the main four components of apparent water losses are illegal consumption, meter reading errors, data handling errors and meter under-registration depending on factors such as installation method, water quality, type and class of water meter [24, 25].

\subsection{Water Losses Levels \& Guidelines}

The issue of water losses and NRW from WDNs is a common problem in many countries such as Turkey where country average NRW is $43.6 \%$ of SIV based on water statistics of Turkish Statistical Institute [26]. Percentage of SIV as the sole PI for water losses in WDNs is not recommended; however, percentage of SIV is the only available PI for water losses in Turkey. Therefore, water losses and NRW levels as a percentage of SIV are summarized in Table 2 for some countries to compare their water losses/NRW levels. It can be noticed from the table that WDNs in some European countries, such as Italy and Portugal, exhibit high water losses, which are above 30\% of SIV. Still, water losses from new WDNs are not expected to be none where the losses could reach up to $10 \%$ of SIV. A few countries have clear and direct guidelines for water losses management although it is a serious problem in many countries.

Table 2. Water losses and NRW levels in some countries around the world

\begin{tabular}{|l|l|l|}
\hline Country & Water Losses / NRW & Reference \\
\hline Turkey & NRW, 43.6\% & {$[26]$} \\
\hline Latin American Water Utilities & NRW, 40-55\% & {$[27]$} \\
\hline Brazil & Water losses, 39.1\% & {$[28]$} \\
\hline Italy & Water Losses, 36\% & {$[29]$} \\
\hline Portugal & Water losses, 36\% & {$[30]$} \\
\hline Slovenia & Water losses, 25-30\% & {$[31]$} \\
\hline Spain & NRW, 24\% & {$[32]$} \\
\hline North America & NRW, 23.1\% & {$[33]$} \\
\hline UK & Water losses, 20-23\% & {$[34]$} \\
\hline Denmark & Water losses, 7\% & {$[35]$} \\
\hline Netherlands & Water losses, 3-7\% & {$[36]$} \\
\hline
\end{tabular}

To control water losses, the DVGW (German Association of the Gas and Water Sector) has issued a guideline titled "W 392 - Network inspection and water losses - activities, procedures and assessments" replacing the old three guidelines namely i) W 390 - Control of Water Supply Networks, ii) W 391 Water Losses in Water Distribution Systems, iii) W 393 - Leak Detection Methods for Water Supply Pipelines. English language version of this guideline, including IWA water balance and definitions, was published. Many concepts such as pressure relation with leakage have also been included in this guideline [37]. German water losses guideline gives volume of real water losses per length of system per unit time as a PI in WDNs. According to the German guideline, water utilities are divided into three different categories based on network structure, namely urban - large cities, urban and rural areas, whereas the level of real water losses is divided into three different categories as low, medium and high. Low level of real water losses might be considered as UARL, medium level should not be more than twice of UARL while high levels of real water losses require a water losses reduction program to be 
undertaken [37]. Italian Decree 99/97, issued in 1997, introduced some recommendations such as DMAs, reduction of excess pressure, flow and pressure measurements in WDNs to reduce water losses. Currently, Italian water utilities are required to calculate and report water losses of each WDN according to Italian Decree 99/97 where volume of water losses as percentage of SIV is given as a PI [38].

In 2014, Turkish Ministry of Forestry and Water Affairs issued a directive titled "Control of Water Losses from Drinking Water Distribution Systems" [39]. The aim of this paper is to discuss and evaluate the contents of this recent Turkish directive on water losses for the first time and to provide recommendations for other countries.

\section{DESCRIPTION OF WATER SERVICES IN TURKEY}

In Turkey, $52.5 \%$ of drinking water is supplied from surface water resources including dams, rivers, lakes and sea while $47.5 \%$ is abstracted from wells and springs [26]. According to the official Turkish water statistics of the year 2012, physical, conventional and advanced treatment methods were applied to $55.3 \%$ of supplied water to the network while the remaining $44.7 \%$ was supplied to the network after only disinfection process due to good raw water quality [26]. In Turkey, there are 30 metropolitan municipalities, 51 provincial municipalities, 519 metropolitan district municipalities, 400 district municipalities, and 396 town municipalities [40]. Municipalities are the only responsible organization for water supply in Turkey and they are classified into five types as follows:

i) Metropolitan municipality: This is the municipality of an urban area that is the central settlement of a province with a population in excess of 750000 capita [41]. A metropolitan municipality serves to a province including both urban and rural areas. Each metropolitan municipality has a legally separate and financially autonomous municipal water and wastewater administration that serves to the whole province.

ii) Provincial municipality: This is the municipality of an urban area that is the central settlement of a province with a population less than 750000 . A provincial municipality provides water services only to the capital city of the province [41].

iii) Metropolitan district municipality: This is the municipality of a central urban settlement of a district within the boundaries of a metropolitan municipality [41]. A metropolitan district municipality is not responsible for water services.

iv) District municipality: All districts in provinces, which are outside the boundaries of a metropolitan municipality, have district municipalities and they provide water services to each district [41].

v) Town municipality: If an urban settlement is neither within a central urban settlement of a province nor of a district, then it has a town municipality and it provides water services to the town [41].

There is no single water related directive and no single institution charged with developing policies for water supply in Turkey. Instead, there are many water related directives and many institutions to apply these directives and this situation causes a lack of coordination and cooperation between the responsible institutions for water. Bank of Provinces, a related establishment of the Ministry of Environment and Urban Planning, is responsible for financing of water supply and sanitation projects. The Ministry of Forestry and Water Affairs is in charge of developing, monitoring and management of water resources while the Ministry of Health is in charge of monitoring drinking water quality. Therefore, a number of governmental entities form the framework of the sector whereas local governments play a central role as water service providers. There was no directive regulating quantitative management of water in WDNs at national level until the issue of the directive entitled "Control of Water Losses from Drinking Water Distribution Systems". The only existing guideline was on "project preparation of water supply 
systems" issued by Bank of Provinces in 1985 which provides figures for water consumption per capita and water pressures. In this guideline, allowable minimum water pressure in WDNs was set as $20 \mathrm{~m}$ $\mathrm{H}_{2} \mathrm{O}$ in settlements with a population up to 50000 and $30 \mathrm{~m} \mathrm{H}_{2} \mathrm{O}$ in settlements with a population in excess of 50001 while the allowable maximum water pressure was $80 \mathrm{~m} \mathrm{H}_{2} \mathrm{O}$. In this guideline, there is also an item describing a target of $10 \%$ water losses reduction in water mains. However, this guideline is all about project preparation and gives no method for operation and evaluation of WDNs.

\section{CHALLENGES OF WATER LOSSES MANAGEMENT IN TURKEY}

Due to a fast increase in population from 45 million in 1980's to 77 million in 2014, available fresh water resources has decreased from around $4000 \mathrm{~m}^{3}$ to $1500 \mathrm{~m}^{3} /$ capita/year, and as a result, Turkey has started to experience water stress [42, 43, 44]. Average NRW in Turkey is $43.6 \%$ of SIV [26]. Many metropolitan municipalities in Turkey have recently established SCADA (Supervisory Control and Data Acquisition) systems for the on-line continuous monitoring of water quantity such as flow rates, water pressures, water levels in distribution reservoirs. SCADA system can provide numerous data sets that can be used for understanding and management of water losses. There are a number of good examples for water losses management in several Turkish municipalities such as Antalya, Istanbul, Ankara, Izmir and Kocaeli. In these municipalities, the WDNs were divided into a suitable number of DMAs where the water inputs to each DMA were intensively monitored by the SCADA systems. On the other hand, there are many other municipalities where there is no single flow or water pressure meter to measure the supplied water and the pressure. The recent values of water losses and NRW in some Turkish municipalities were gathered following a survey carried out by the Turkish Ministry of Forestry and Water Affairs, as shown in Figure 1. In this figure, a comparison of water losses and NRW values in some municipalities of Turkey is illustrated based on annual reports of 2013 [45, 46]. In Figure 1, water losses and NRW values were sorted in a descending order of population for municipalities which starts with the highest population of around 14 million and ends with the lowest population of around 500000 . The average value of water losses in these municipalities is about $39.2 \%$ while NRW is about $43.2 \%$. Water losses values in Istanbul, Diyarbakir, Safranbolu and Çanakkale municipalities were reported as equal to NRW rates. On the other hand, NRW value in Malatya municipality was reported as almost two times more than water losses value. This evaluation shows the necessity of a detailed water audit and common terminology for water losses management at national level in Turkey.

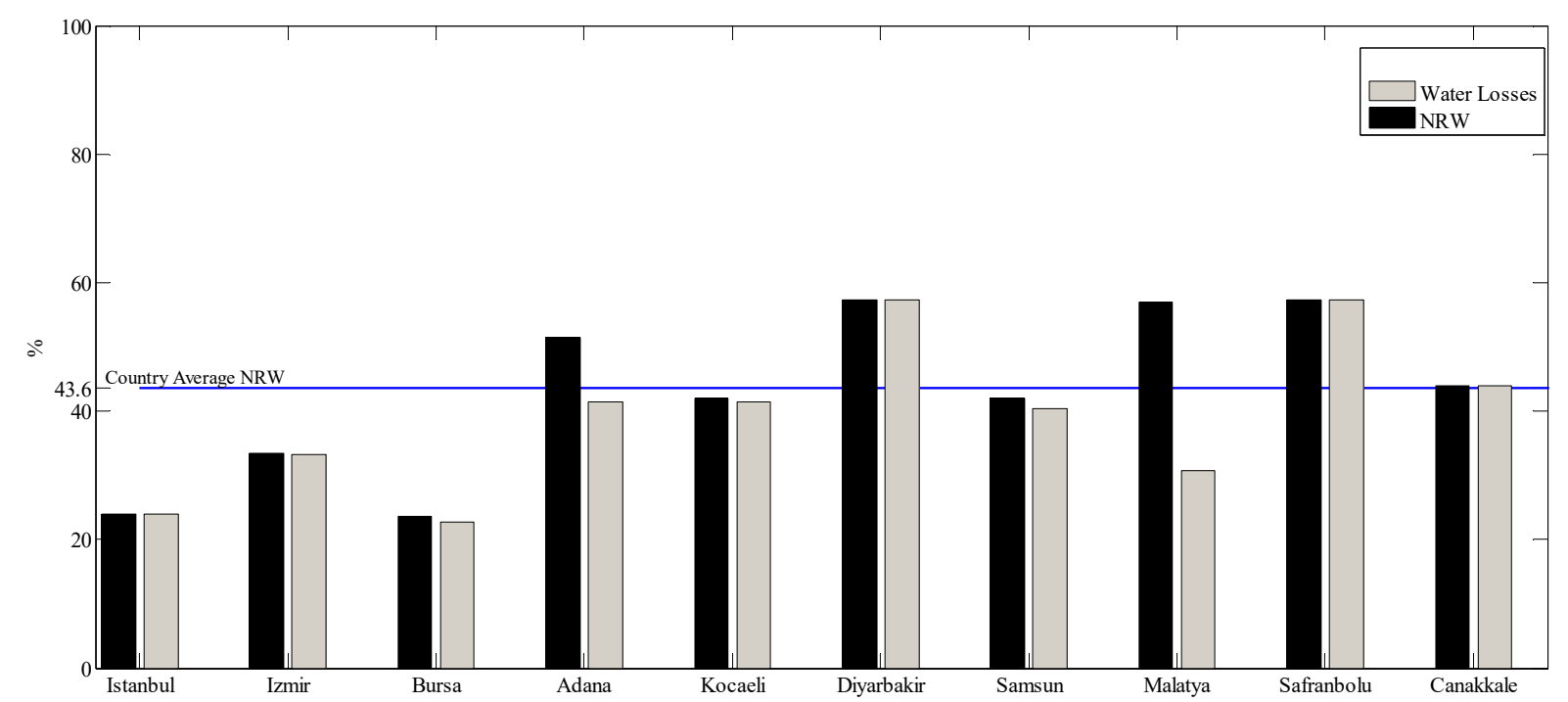

Figure 1. Water losses and NRW values of some municipalities in Turkey [26, 45, 46] 
Aging infrastructure, inadequate assets management, poor maintenance of networks, water theft, and insufficient reliable data for evaluation of WDNs are the main challenges of water losses management in Turkey. Many municipalities started to improve and update their infrastructure. It was estimated that around $50 \%$ of WDNs in Turkey is older than 50 years old [47]. The elements and components of WDNs, which are known only by a few technicians, are not digitized into GIS.

There are many small municipalities that have no facilities and/or activities for estimating or reducing water losses. In many cases, the WDNs at these municipalities have no single flow or pressure meter; therefore the amount and cost of water losses are not properly quantified. Funding for water losses management is required in short term; however it is a self-financing program in long term. Unfortunately, there is often a shortage to get funds for such activities [8]. Consequently, the average value of water losses in Turkey is still high when compared with many European countries.

\section{THE TURKISH DIRECTIVE ON WATER LOSSES CONTROL}

In 2014, Turkish Ministry of Forestry and Water Affairs issued a directive titled "Control of Water Losses from Drinking Water Distribution Systems" to reduce water losses from WDNs [39]. The directive has three parts. The first part includes aim, scope, legal basis and definitions. The second part is about the management of water distribution systems and reduction of water losses while the third part is about reporting. Technical procedure of this directive is under development by the Ministry of Forestry and Water Affairs. In the following sections, some brief information about the new directive is introduced, rather than a translation of the whole contents, to present a good code of practice. The aim of the directive is to protect water resources and provide water use efficiency through reduction of water losses from water distribution systems. In this manner, this directive could be a good guide and example for many developed and developing countries.

\subsection{Management of WDNs and Reduction of Water Losses}

The directive [39] states that municipalities should carry out the following activities to manage WDNs:

- Water consumption and unit cost of water supply should be determined and submitted as an annual report each year.

- Municipalities should determine their water consumption and budget needs of water supply, carry out cost benefit analysis for water supply and include necessary precautions for water losses reduction methods in their strategic plans.

- Monitoring, reporting and determination of water consumption and revenues should be carried out. For this purpose, customer water meters should be installed at all water users for analysis of water audit, measurements and monitoring of water pressure at critical points should be conducted.

- Digitizing the elements of WDNs and updating existing GISs of WDNs should be carried out by the municipalities.

Recommended activities under the title of reduction of water losses start with water balance, which is needed to adopt new technologies such as use of flow meters for analysis of water audit. The recommended form of water balance follows the IWA Best Practice of water balance and the definitions of its components with a slight change in physical losses components [4], as illustrated in Table 3. IWA Best Practice of water balance includes three components for physical losses: i) leakage on transmission and distribution mains, ii) leakage and overflows at storage tanks, iii) leakage on service connections up to point of customer water meter. Leakage on transmission and distribution mains and leakage on service connections up to point of customer water meter components were unified as one component, so physical components of water balance recommended by the directive has now two components for physical losses. 
Karadirek / Anadolu Univ. J. of Sci. and Technology - A - Appl. Sci. and Eng. 17 (3) - 2016

Table 3. Recommended form of annual water balance [39]

\begin{tabular}{|c|c|c|c|c|}
\hline \multirow{5}{*}{$\begin{array}{l}\text { System Input } \\
\text { Volume } \\
\ldots \mathbf{m}^{\mathbf{3}} / \mathbf{y e a r} \\
\mathbf{( 1 0 0 \% )}\end{array}$} & \multirow{2}{*}{$\begin{array}{c}\text { Authorized } \\
\text { Consumption } \\
\ldots \text { m }^{3} / \text { year } \\
(\ldots \%)\end{array}$} & $\begin{array}{l}\text { Billed Authorized } \\
\text { Consumption } \\
\ldots \mathbf{m}^{3} / \text { year } \\
(\ldots \%)\end{array}$ & $\begin{array}{c}\text { Billed Metered Consumption } \\
\ldots . . \mathbf{m}^{3} / \mathbf{y e a r} \\
(\ldots \%)\end{array}$ & $\begin{array}{c}\text { Revenue Water } \\
\ldots . \mathbf{m}^{3} / \text { year } \\
\text { (...\%) }\end{array}$ \\
\hline & & $\begin{array}{c}\text { Unbilled Authorized } \\
\text { Consumption } \\
\ldots . \mathbf{m}^{\mathbf{3}} / \text { year } \\
(\ldots \%)\end{array}$ & 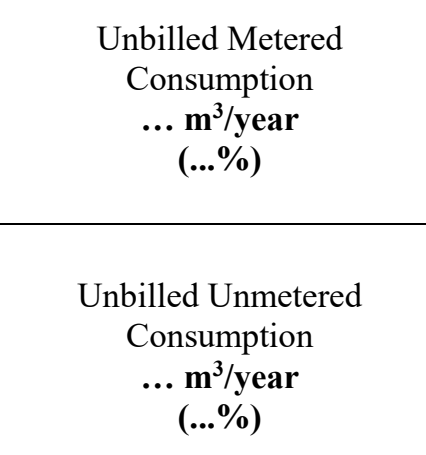 & \multirow{4}{*}{$\begin{array}{l}\text { Non-revenue } \\
\text { Water } \\
\ldots \text { m }^{3} / \text { year } \\
(\ldots \%)\end{array}$} \\
\hline & \multirow{3}{*}{$\begin{array}{c}\text { Water Losses } \\
\ldots . \mathbf{m}^{3} / \text { year } \\
(\ldots \%)\end{array}$} & $\begin{array}{c}\text { Apparent Losses } \\
\ldots \mathbf{m}^{3} / \mathbf{y e a r} \\
\mathbf{( . . . \% )}\end{array}$ & $\begin{array}{l}\text { Unauthorized Consumption } \\
\qquad \ldots \mathbf{m}^{3 / y e a r} \\
(\ldots \%)\end{array}$ & \\
\hline & & \multirow{2}{*}{$\begin{array}{c}\text { Real Losses } \\
\ldots \mathbf{m}^{3} / \mathbf{y e a r} \\
(\ldots \%)\end{array}$} & $\begin{array}{l}\text { Leakage on Transmissions } \\
\text { and Service Connections } \\
\ldots . \mathbf{m}^{\mathbf{3} / \mathbf{y e a r}} \\
(\ldots \mathbf{. \%})\end{array}$ & \\
\hline & & & $\begin{array}{l}\text { Leakage and Overflows at } \\
\text { Reservoirs } \\
\ldots \ldots \ldots \ldots \ldots \ldots \ldots \ldots \\
\mathbf{m}^{3} / \mathbf{y e a r} \\
\text { (...\%) }\end{array}$ & \\
\hline
\end{tabular}


Karadirek / Anadolu Univ. J. of Sci. and Technology - A - Appl. Sci. and Eng. 17 (3) - 2016

Municipalities should carry out the following activities to reduce water losses:

- Pressure management: Maximum pressure is defined as $60 \mathrm{~m} \mathrm{H}_{2} \mathrm{O}$ in the directive. The former value of the allowable maximum pressure in WDNs was $80 \mathrm{~m} \mathrm{H}_{2} \mathrm{O}$. The former allowable maximum pressure in WDNs has been replaced with the new value.

- Speed and quality of repairs: Municipalities should provide proper repair where pipe bursts are seen.

- Maintenance of pipeline systems: Rehabilitation, maintenance and repairs should be carried out regularly depending on system needs.

- Active leakage control: Municipalities should carry out an active leakage control program using proper monitoring systems such as SCADA.

- Pipeline and assets management: Selection and installation of components of WDNs should be done properly to prevent physical water losses.

- Forming pressure zones and DMAs: New WDNs should be designed considering pressure zones and DMAs. Hydraulic modelling should be carried out in existing WDNs which should be divided into DMAs and pressure zones where it is applicable.

- Prevention of illegal usage: installation of proper consumer water meters based on consumption profile of consumers, replacement of water meters that are older than ten years with new and more accurate ones should be practiced to reduce apparent losses.

- Appropriate technologies for detection of pipe bursts should be selected to reduce physical water losses.

- Employment of qualified personnel to control and reduce water losses is necessary as well.

Metropolitan and provincial municipalities are obliged to reduce water losses by $30 \%$ of SIV within 5 years and $25 \%$ of SIV within 9 years after the issue of the new directive. Additionally, other municipalities are obliged to reduce water losses by $30 \%$ of SIV within 9 years and $25 \%$ of SIV within 14 years [39].

\subsection{Reporting Duties of Water Authorities}

According to the new directive, water authorities are obliged to give information about water consumption, water losses, NRW and other data related to management of WDNs. For this purpose, each water authority should prepare an annual report including general information about water losses reduction program carried out by the water authority. Recommended water balance, given in Table 3, and an inventory form, given in Table 4, should be prepared by each municipality annually [39].

\subsection{Evaluation of the Turkish Directive on Water Losses}

The Turkish directive on water losses management gives the percentage of SIV as a water loss target and PI. Systems with higher SIV show lower level of water losses compared to systems with lower SIV [37]. Expressing water losses as a percentage does not reflect any other influencing factors such as number of service connections and the length of water mains; however it is better than having no targets. The elements and components of WDNs, which are vital for dividing WDNs into DMAs, modeling issues and using PIs such as ILI which allows international comparisons of assessment of WDNs, are only known by a few technicians in many municipalities. So it seems that many municipalities are not ready for such activities yet. The municipalities are recently obliged to digitize and update the components of WDNs, to install flow meters and customer water meters. Therefore such activities might be conducted after these requirements are implemented. Although water potential and the conditions of network structures in Turkey differ between regions, the target level of water losses is the same which is also independent from economic level of water losses. Financial resources should be allocated to enhance the basis in terms of capacity building of both infrastructure and human resources with the issue of the new directive. Raising awareness for decision makers and training for technical personnel are required to achieve the targets given in the new directive. 
Karadirek / Anadolu Univ. J. of Sci. and Technology - A - Appl. Sci. and Eng. 17 (3) - 2016

Table 4. Inventory form of water losses in water distribution networks [39]

\begin{tabular}{|c|c|c|c|c|}
\hline & & Groundwater & Surface water & Total \\
\hline 1 & $\begin{array}{l}\text { Water abstraction for municipal water supply } \\
\text { network }\left(\mathrm{m}^{3} / \mathrm{y}\right) \text { (Name of source) }\end{array}$ & & & \\
\hline 2 & $\begin{array}{l}\text { Treated water }\left(\mathrm{m}^{3} / \mathrm{y}\right) \\
\text { (If treatment applicable) }\end{array}$ & & & \\
\hline 3 & $\operatorname{SIV}\left(\mathrm{m}^{3} / \mathrm{y}\right)$ & & & \\
\hline 4 & Number of consumers & & & \\
\hline 5 & Authorized consumption $\left(\mathrm{m}^{3} / \mathrm{y}\right)$ & & & \\
\hline 6 & Water Losses $\left(\mathrm{m}^{3} / \mathrm{y}\right)$ & & & \\
\hline 7 & Length of mains (m) & & & \\
\hline 8 & Is there any SCADA system? & Yes & & No \\
\hline 9 & Is there any GIS software? (If yes, define it.) & & & \\
\hline 10 & $\begin{array}{l}\text { Is there any consumer information system? } \\
\text { (If yes, define it.) }\end{array}$ & & & \\
\hline 11 & $\begin{array}{l}\text { Is there any work for inspection and reduction of } \\
\text { water losses? (Active leakage management, } \\
\text { DMAs, pressure management, etc.) } \\
\text { (If yes, define it.) }\end{array}$ & Yes & & No \\
\hline 12 & $\begin{array}{l}\text { Is there any working team for inspection of } \\
\text { water losses? (If yes, indicate the number of } \\
\text { employees.) }\end{array}$ & Yes & & No \\
\hline 13 & $\begin{array}{l}\text { Number of reported and unreported bursts in } \\
\text { WDN. }\end{array}$ & $\begin{array}{l}\text { Reported: } \\
\text { Unreported: }\end{array}$ & & \\
\hline 14 & Unit nrice of water ner $\mathrm{m}^{3}$ & Residential & Industrial & Other \\
\hline 15 & Types and numbers of customer water meters & & & \\
\hline
\end{tabular}

\subsection{Evaluation of the Turkish Directive on Water Losses}

The Turkish directive on water losses management gives the percentage of SIV as a water loss target and PI. Systems with higher SIV show lower level of water losses compared to systems with lower SIV [37]. Expressing water losses as a percentage does not reflect any other influencing factors such as number of service connections and the length of water mains; however it is better than having no targets. The elements and components of WDNs, which are vital for dividing WDNs into DMAs, modeling issues and using PIs such as ILI which allows international comparisons of assessment of WDNs, are only known by a few technicians in many municipalities. So it seems that many municipalities are not ready for such activities yet. The municipalities are recently obliged to digitize and update the components of WDNs, to install flow meters and customer water meters. Therefore such activities might be conducted after these requirements are implemented. Although water potential and the conditions of 
network structures in Turkey differ between regions, the target level of water losses is the same which is also independent from economic level of water losses. Financial resources should be allocated to enhance the basis in terms of capacity building of both infrastructure and human resources with the issue of the new directive. Raising awareness for decision makers and training for technical personnel are required to achieve the targets given in the new directive.

\section{CONCLUSION}

Management and reduction of water losses in WDNs is a global issue and it requires a common understanding from both social and technical sciences. The social part is related to conservation of water for the next generations and maintaining direct and reliable regulations for coordination between the responsible organizations and enforcement. The technical part is related to use of the best technology to reduce water losses in WDNs using cost effective approaches. It is inevitable to eliminate water losses totally and even the existing WDNs in highly developed countries have real and apparent water losses. The critical action is to reduce water losses to the minimum acceptable level considering both economical and technical constraints. Municipalities in Turkey are now obliged to manage water losses with the issue of the new directive that will help increasing awareness for protection of water resources and saving water. Water losses management needs investment on some new technologies such as SCADA and GIS which are crucial for management and operation of water supply systems. With the application of the new directive, municipalities will be forced to invest in such technologies to improve their service and contribute to resilience of water in WDNs. All these improvements necessitate funding in short term, however, water losses management is a self-financing program in long term. Following the positive advances in water losses reduction programs, public perception on the quality of distributed water will be improved in the successful municipalities and public will be more volunteered to consume tap water instead of bottled water. Reducing water losses in WDNs and the overall improvements in water supply systems will contribute to protect water quality in WDNs and reduce possible contamination risks of distributed water. Consequently, management of water losses in WDNs will contribute to protection of public health by reducing the risks for water-borne diseases.

\section{REFERENCES}

[1] United Nations Water - Climate change adaptation: The pivotal role of water, 2014. [Online]. Available: http://www.unwater.org/downloads/unw_ccpol_web.pdf (Accessed 3 December 2014).

[2] Dimkic MA, Milovanovic M, Dimkic D. Sustainable and Adaptive Water Management: Case Study of Water Management in Serbia. Water Research and Management 2011; 1(4): 9-19.

[3] Kingdom B, Liemberger R, Marin P. The challenge of reducing non-revenue water (NRW) in developing countries, 2006. [Online]. Available:http://siteresources.worldbank.org/INTWSS/Resources /WSS8fin4.pdf. (Accessed 10 February 2015).

[4] Lambert A, Brown T, Takizawa M, Weimer D. Review of Performance Indicators for Real Losses from Water Supply Systems. J. Water Supply: Res. T.-AQUA 1999; 48: 227-237.

[5] Mckenzie R, Seago C. Assessment of real losses in potable water distribution systems: some recent developments. Water Science and Technology: Water Supply 2005; 5(1): 33-40.

[6] Tabesh M, Asadiyani Y, Burrows R. An integrated model to evaluate losses in water distribution systems. Water Resources Management 2009; 23(3): 477-492. 
Karadirek / Anadolu Univ. J. of Sci. and Technology - A - Appl. Sci. and Eng. 17 (3) - 2016

[7] Control and Mitigation of drinking water losses in distribution systems., 2010. [Online]. Available: http://water.epa.gov/type/drink/pws/smallsystems/upload/Water_Loss_Control_508_FINALDEc.pdf. (Accessed: 19 December 2014).

[8] Fanner P. Non-Revenue Water reduction - Contracts and illustrated examples, 2008. [Online]. Available:http://www.miya-water.com/user_files/Data_and_Research/miyas_experts_articles/2_NRW /07_Non-Revenue \%20Water\%20reduction\%20Contracts\%20and\%20illustrated\%20examples.pdf (Accessed 25 February 2015).

[9] Fumani SMR. Contaminant intrusion in water distribution systems: advanced modelling approaches. $\mathrm{PhD}$, The University of British Columbia, Canada, 2013.

[10] Mutikanga HE. Water loss management: Tools and methods for developing countries. PhD, UNESCO-IHE, Netherlands, 2012.

[11] Tooms S, Pilcher R. Practical guidelines on efficient water loss management. Water 21- Magazine of the International Water Association 2006; 8(4): 47.

[12] Mutikanga HE, Sharma SK, Vairavamoorthy K. Multi-criteria decision analysis: a strategic planning tool for water loss management. Water Resources Management 2011; 25 (14): 3947-3969.

[13] Kanakoudis V, Gonelas K, Tolikas D. Basic principles for urban water value assessment and price setting towards its full cost recovery-pinpointing the role of the water losses. J. Water Supply Res. Technol. AQUA 2011; 60(1), 27-39.

[14] Alegre H, Hirnir W, Baptista JM, Parena R. IWA Manual Best Practice Series: Performance Indicators for Water Supply Services. 1st ed. London, England: IWA Publishing, 2000.

[15] McKenzie R, Seago C, Liemberger R. Benchmarking of losses from potable water reticulation systems results of IWA Task Team. In: IWA International Conference 'WaterLoss 2007'; 23-26 September 2007; Bucharest, Romania.

[16] Kanakoudis V, Tsitsifli S. Water volume vs. revenues oriented water balance calculation for urban water networks: The "Minimum Charge Difference" component makes a difference! In: IWA International Conference 'WaterLoss 2010'; 6-9 June 2010; Sao Paolo, Brazil.

[17] Alegre H, Baptista JM, Cabrera E Jr, Cubillo F, Duarte P, Hirner W, Parena R. IWA Manual Best Practice Series: Performance Indicators for Water Supply Services. 2nd ed. London,England: IWA Publishing, 2006.

[18] Winarni W. Infrastructure Leakage Index (ILI) as Water Losses Indicator. Civil Engineering Dimension 2009; 11(2): 126-134.

[19] Liemberger R, McKenzie R. Accuracy Limitations of the ILI: Is It an Appropriate Indicator for Developing Countries? In: IWA Leakage 2005 Conference; 12-14 September 2005; Halifax, Canada.

[20] Morrison J. Managing leakage by District Metered Access: a practical approach. Water 21Magazine of the International Water Association 2004; 6 (1): 44-46.

[21] Sturm R, Thornton J. Proactive leakage management using District Metered Areas (DMA) and pressure management-Is it applicable in North America In: IWA Leakage 2005 Conference; 12-14 September 2005; Halifax, Canada. 
[22] Lambert A. International Report: Water Losses Management and Techniques. Water Supply 2002; 2(4): $1-20$.

[23] Karadirek IE, Kara S, Yilmaz G, Muhammetoğlu A, Muhammetoğlu, H. Implementation of hydraulic modelling for water-loss reduction through pressure management. Water Resources Management 2012; 26 (9): 2555-2568.

[24] Rizzo A, Vermersch M, John GS, Micallef G, Pace R. Apparent Water Loss Control: The Way Forward. Water 21- Magazine of the International Water Association 2007; 9 (4): 45-47.

[25] Kanakoudis V, Muhammetoğlu H. Urban water pipe networks management towards non-revenue water reduction: Two case studies from Greece and Turkey. Clean: Soil, Air, Water 2014; 42(7): 880-892.

[26] Turkish Statistical Institute Municipal Water Statistics, 2012. [Online]. Available: http://www.turkstat.gov.tr/PreHaberBultenleri.do?id=16171 (Accessed 7 December 2014).

[27] Corton ML, Berg SV. Benchmarking Central American Water Utilities, 2007. [Online]. Available: http://warrington.ufl.edu/centers/purc/purcdocs/papers/0729_Berg_Benchmarking_Central.pdf (Accessed 21 December 2014).

[28] Cheung PB, Girol GV. Night flow analysis and modeling for leakage estimation in a water distribution system. In Boxall J, Maksimovic C, editors. Integrating Water Systems. London, England: Taylor and Francis Group, 2009. pp.509-515.

[29] OECD environmental performance reviews: Italy. Paris, France: OECD Publishing, 2013.

[30] OECD environmental performance reviews: Portugal. Paris, France: OECD Publishing, 2011.

[31] OECD environmental performance reviews: Slovenia. Paris, France: OECD Publishing, 2012.

[32] OECD environmental performance reviews: Spain. Paris, France: OECD Publishing, 2015.

[33] Simmons WG. Going Viral: Emerging benchmarks for water efficiency - Water loss in North America,2014.[Online]Available:http:/www.ncsu.edu/wrri/pdfs/pastevents/ac2014/1B/B4\%20Simmons \%20-\%20New.pdf (Accessed 9 March 2015).

[34] Service and delivery-performance of the water companies in England and Wales 2009-10 report, 2010.[Online]. Available:http://www.ofwat.gov.uk/regulating/casework/reporting/rpt_los_2009-10.pdf (Accessed 25 March 2015).

[35] Water in figures: Danish Water and Wastewater Association's Benchmarking and Water Statistics, 2010.[Online].Available:http://www.danva.dk/Admin/Public/DWSDownload.aspx?File=\%2fFiles\%2f Filer\%2fUdgivelser\%2fBenchmarking\%2fVand $+\mathrm{i}+$ tal\%2fWater_in_Figures_2010.pdf (Accessed 27 March 2015)

[36] Beuken RHS, Lavooij CSV, Bosch A, Schaap PG. Low leakage in the Netherlands Confirmed. In: 8th Annual Water Distribution Systems Analysis Symposium; 27-30 August 2006; Cincinnati, OH, USA.

[37] Liemberger R. The New German water loss regulations in context with other international applications of the IWA water balance and real loss performance indicators. International Water Association Specialist Workshop; 24 February 2005; Queensland, Australia. 
[38] Fantozzi M. Italian case study in applying IWA WLTF approach: results obtained. In: Thornton J, Sturm R, Kunkel G, editors. Water Loss Control, New York, NY, USA: McGraw-Hill, 2008. pp. 421432.

[39] Turkish Ministry of Forestry and Water Affairs, İçme Suyu Temin ve Dağıtım Sistemlerinde Su Kayıplarının Kontrolü Yönetmeliği, 8 May 2014, Official Gazette No: 28994.

[40] Turkish Ministry of Interior, Civil Administration Servives, 2016. [Online]. Available: https://www.e-icisleri.gov.tr/Anasayfa/MulkiIdariBolumleri.aspx

[41] Local governments in Turkey, 2014. [Online].Available:http://www.migm.gov.tr/en/PDF/General Information.pdf (Accessed: 20 March 2015).

[42] Turkish Statistical Institute Population Projection from 2013 to 2075, 2013. [Online]. Available: http://www.turkstat.gov.tr/PreHaberBultenleri.do?id=15844. (Accessed: 13 December 2014).

[43] Fresh water resources Turkey: Present situation in Turkey, 2014. [Online]. Available: http://www.climateadaptation.eu/turkey/fresh-water-resources/. (Accessed 9 February 2015).

[44] Annual Report of Turkish General Directorate of State Hydraulic Works, 2012. [Online]. Available: http://www.dsi.gov.tr/docs/stratejik-plan/dsi-2012-faal\%C4\%B1yet-raporu.pdf?sfvrsn=2 (Accessed 20 January 2015).

[45] Adiguzel A. İçme suyu temin ve dağıtım sistemlerinde su kayıplarının kontrolu, 2014. [Online]. Available:http://suyonetimi.ormansu.gov.tr/Libraries/su/Su_Ekonomisi_ve_Verimliligi_Sube_Mudurlugu. sflb.ashx (Accessed 16 February 2015)

[46] Annual report of Istanbul water and wastewater administration, 2013. [Online]. Available:http:/www.iski.gov.tr/Web/UserFiles/File/faaliyetraporu2008/faaliyet_raporu2013.pdf (Accessed: 16 November 2014).

[47] Öztürk I, Uyak V, Çakmakcı M, Akca L. Dimension of water loss through distribution system and reduction methods in Turkey. In: River Basin Management Congress; 22-24 March 2007; Antalya, Turkey. 